\title{
Comprehensive approach to expert identification of the common source of origin of drugs
}

\author{
(C) Anna A. Zavialova, ${ }^{1}{ }^{+}$and Vasily V. Zavialov ${ }^{2}$ \\ ${ }^{1}$ Moscow University of the Ministry of Internal Affairs of Russia Named after V.Ya. Kikotya. \\ Akademika Volgina St., 12. Moscow, 117437.Russia.E-mail: achkasova79@mail.ru \\ 27 Scientific Center of the Ministry of Defense of the Russian Federation. \\ Brigadirsky Lane, 13. Moscow, 105005. Russia.
}

\begin{abstract}
*Supervising author; ${ }^{+}$Corresponding author
Keywords: drugs and psychotropic substances, common source of origin, packaging and tablet form, comprehensive comparative research, trace evidence, physico-chemically research.
\end{abstract}

Abstract
The article proposes an algorithm for conducting a comprehensive comparative study of various drug samples to determine their common source of origin using not only methods of physical and chemical analysis, but also the possibilities of tracological examination of their packages and tablet forms.

The use of this algorithm with expert research for establishment of common origin of different samples of controlled substances will help to achieve the study objectives with maximum efficiency and speed is extremely important aspect to optimize the timing of expert studies in the framework of forensic support operative-investigative and procedural activities of law enforcement agencies to curb illegal traffic in narcotic drugs and psychotropic substances.

The authors indicate that when conducting a comprehensive comparative study of samples of narcotic drugs and psychotropic substances both in the framework of operational search activities and in the course of forensic examination, employees of expert forensic units of internal affairs bodies can assist criminal investigation officers in forming an evidence base on the facts of direct trafficking of controlled substances, contact of a suspect with controlled substances, in particular with a specific sample of a drug or psychotropic substance, production, storage, transportation of controlled substances by a suspected person in principle and a specific sample of them, the belonging of various persons suspected of involvement in the illegal trafficking of controlled substances to one organized criminal group, as well as the identification of the entire chain involved in the organization of this illegal trafficking.

Provides options to make conclusions on the results of comprehensive comparative studies of different samples of drugs and psychotropic methods of physico-chemical and tracological examination and their interpretation for the purposes of detection and suppression of illegal drug trafficking.

\section{References}

[1] V.V. Zavyalov, G.V. Lyubetsky, P.A. Rodionov, A.A. Zavyalova, T.A. Zotov, S.I. Semenov. Criminalistic research of packages and tableted forms of narcotic drugs and psychotropic substances in order to establish a common source of origin: Methodological recommendations. Moscow: ECC of the Ministry of Internal Affairs of Russia. 2014. 40p. (russian)

[2] V.V. Zavyalov, A.A. Zavyalova, G.V. Lyubetsky, V.V. Gladyrev et al. Methodological foundations for establishing a common source of origin of synthetic narcotic drugs and psychotropic substances: Methodological recommendations. Moscow: ECC of the Ministry of Internal Affairs of Russia. 2013. 104p. (russian)

[3] I.M. Fitsev, V.K. Blokhin, G.K. Budnikov, N.A. Fitseva. Chemical-analytical diagnostics in the forensic examination of materials, substances and products. Factory laboratory. Diagnostics of materials. 2004. Vol.70. No.4. P.3-15. (russian)

[4] Fitsev I.M., Blokhin V.K., Budnikov G.K. Chromatographic methods in forensic examination. Journal. analyte. chemistry. 2004. Vol.59. No.12. P.1289-1298. (russian)

[5] Mailis N.P. Fire and technical examination: a course of lectures. IN FGBOU Russian state University of justice. Moscow: RSUP. 2015. 273p. (russian)

[6] Bulletin on Narcotic Drugs Volume LVII, No. 1 and 2, 2005 Science and drug control: the role of scientific and laboratory expertise. UNITED NATIONS New York. 2007. 272p. (russian) 